\title{
FINNISH PRESCHOOL AND FIRST-GRADE CHILDREN'S USE OF MEDIA AT HOME
}

\author{
Riitta-Liisa Korkeamäki \\ University of Oulu \\ Finland
}

\author{
Mariam Jean Dreher \\ University of Maryland, College Park \\ USA
}

\author{
Asko Pekkarinen \\ University of Oulu \\ Finland
}

\begin{abstract}
We investigated Finnish children's use of print and electronic media in the home and their literacy development. Questionnaire data from 857 parents of preschoolers (collected in 2006 and 2007) and first graders (2008) showed that homes were well equipped with electronic media including Internet access in almost every home, although only a third of the children used the Internet. Television, print media, and videos/DVDs were more commonly used than computers. Most first graders but few preschoolers had mobile phones. Most parents read bedtime stories, had a sizable number of children's books, and library visits were common. Boys' and girls' skills in reading did not differ at the beginning of their preschool year. But girls showed more interest in writing while boys played more console and computer-based games. Most first graders were reading early in the school year, suggesting that electronic media are not harmful but may even support literacy development.
\end{abstract}

Keywords: print literacy, media literacy, electronic media, family literacy practices, early literacy development, preschool, first grade.

\section{INTRODUCTION}

Young children's use of print and electronic media can influence the way they come to understand literacy, which, in turn, can impact their future achievement as readers. Considerable research details how young children's literacy-related practices contribute to their literacy development, particularly in practices relevant to print media (Teale \& Sulzby, 1989; Yaden, Rowe, \& MacGillivray, 2000). But children are increasingly surrounded by and engaged with nonprint media such as television, computers, the Internet, and mobile phones. As documented in research in the USA and the UK, for example, children watch considerable

(C) 2012 Ritta-Liisa Korkeamäki, Mariam Jean Dreher, \& Asko Pekkarinen, and the Agora Center, University of Jyväskylä

URN:NBN:fi:jyu-201211203031 
amounts of television (e.g., Marsh et al., 2005). Similarly, surveys evidence the increasing use of newer technologies, such as computer software and the Internet, by children of early school age and younger (Common Sense Media, 2011; Rathbun \& West, 2003; Rideout \& Hamel, 2006). In fact, commercial markets are targeting even very young children (Vandewater et al., 2007). Studies have found that children use a variety of technologies (e.g., Blanchard \& Moore, 2010) and that family literacy practices have changed from the use of mostly print-based texts to techno-literacy practices involving multimodal texts using new technology such as computers, console games, and mobile phones (Marsh, 2004). Although the role of moving and still images is increasing, words and letters on the screen continue to be important (Marsh, 2009).

Considerable debate on the effects of technology on young children has taken place. With regard to electronic media, television has been the most widely researched, with evidence indicating that, depending on the amount and type, television viewing can have both positive and negative effects on literacy (e.g., Neuman, 1988; Schmidt et al., 2006). However, much less research is available on the effects of newer technologies (see Rideout, Foehr, \& Roberts, 2010). Some view newer digital technologies as a threat to the use of books, newspapers, and magazines (Rideout et al., 2010). In contrast, others view new technologies as something to be valued, and advocate expanding the perspective on what counts as literacy in young children (e.g., Karchmer, Mallette, \& Leu, 2002).

But what is the situation in Finland? Our purpose in this study was to examine young Finnish children's engagement with newer technologies, as well as more traditional media such as television, radio, and print-based material in the home. Because most research on young children's media use in Finland has addressed only some aspects of media use, we were interested in including all these media in the same study. Furthermore, we also investigated children's emerging literacy knowledge in order to learn how these media may contribute to that knowledge. As we detail below, Finland is characterized by a strong tradition of valuing reading, and, as research suggests, children's easy access to technologies. Thus, Finland is an interesting context in which to explore young children's media use, with an eye toward shedding light on the debate about the effects of technology on young children's literacy development. Possible outcomes of these trends could result in, for example, newer technologies displacing older media such as books, or literacy-related practices reflecting expanded media use, with older media being supplemented with rather than replaced by newer technologies.

Finland is a reading nation. Finns subscribe to and read newspapers at an exceptionally high level, when compared with international trends (Sauri, 2007). In addition, Spadaro (2002) reported that Finns use libraries more frequently than any other nation in the European Union.

Recently, however, some decline in book reading in Finland has been noticed. For example, Lappalainen (2008) found that seventh-grade students borrowed fewer library books in 2008 than their counterparts in 2002. Similarly, in a Gallup Finnish International poll (YIPPEE, 2008), 12\% of 3- to 16-year-olds reported that they never read books although only $2 \%$ reported never watching television. In addition, the poll indicated that daily use of the Internet is more frequent among 3- to 16 -year-olds than reading books ( $63 \%$ vs. $48 \%$, respectively). Such data seem to suggest that newer technologies are rivaling the use of traditional media such as children's books. However, other studies suggest that reading is still a quite frequent activity in Finland. For example, Hirvonen (2012) found that $46 \%$ of first graders (7-year-olds) reported reading books daily. Thus, additional research is needed to address the interplay of Finnish children's reading habits and use of other media, especially for young children. 
Many Finnish researchers have studied school-age children's media use (children start school at age 7 in Finland). For example, studies indicate that digital gaming is common among school-age children. Ermi, Mäyrä, and Heliö (2005) found that $98 \%$ of 10 - to 12 -yearolds reported playing digital games at least occasionally, with $75 \%$ doing so at least once a week. All the boys in that study played digital games at least to some extent, but a few girls reported they did not play such games at all. Typically, the playing took place with a home computer ( $88 \%$ of families had a computer). Moreover, $54 \%$ of children indicated they had other equipment for playing games, with only 4\% reporting that they did not. Among 8- to 10 -year-olds, Matikkala and Lahikainen (2005) found that $84 \%$ of boys reported playing computer games at least once a week, but only $54 \%$ of girls did so. These children also used media for communication: 58\% used mobile phones, 39\% sent text messages, 31\% used email, and 16\% participated in group e-mails between several writers. Hirvonen's (2012) research indicated that $42 \%$ of 7 - to 11-year old children played computer, console, or Internet games daily. In a study of 11-year-olds' Internet use, Oinas-Kukkonen and Kurki (2009) found that $90 \%$ reported regular use, but with different patterns by gender. While $60 \%$ of the boys reported playing Internet games daily, only $36 \%$ of the girls did so. Instead, the girls used the Internet primarily for social interaction. Suoninen (2011) found that $86 \%$ of 7 and 8 -year-old boys and $65 \%$ of girls played digital games weekly, with $30 \%$ of boys and $15 \%$ of girls playing these games daily. Girls mainly played platform games and learning games; boys preferred platform games, as well as driving, sports, and adventure games.

Research on school-age Finnish children also indicates that watching television is common. For example, in Suoninen's (2011) study, parents reported that $66 \%$ of 7- and 8-yearolds watched television daily. Similarly, Uusitalo, Vehmas, and Kupiainen (2011) found that the small groups of 11-year-olds they interviewed reported watching 96 minutes of television a day, on average, whereas the 14-year-olds reported watching 88 minutes of television.

Similarly, television viewing has also been studied with below school-age children. Valkonen, Pennonen, and Lahikainen (2005) interviewed 5- and 6-year-old children and surveyed their parents in two large Finnish cities. On average, these children watched television 1.4 hours per day, but the time varied from 36 minutes to 4.2 hours. Generally, children watched only children's programs on their own, while other programs were watched with their parents. In such circumstances, parents were able to influence which programs were viewed as well as to share and reflect on what they and their children had seen. They also were able to restrict their children's television viewing. Similarly, Korhonen (2008) found that 5- and 6year-old children typically watched 1 to 2 hours of television daily, and that $90 \%$ of the parents she surveyed reported controlling their children's television access. Although parents sometimes worry that watching television can be harmful to their children, some parents in Korhonen's study reported that their children benefited from watching television, by learning new vocabulary and ideas, as well as widening their worldview. And, of course, parents report that television entertains their children (Koivusalo-Kuusivaara, 2007).

Indeed, television viewing has been the focus of many studies. But in a recent survey, Suoninen (2011) investigated not only children's television viewing but also their use of media more widely. Her results confirmed widespread television use, with parents reporting that $34 \%$ of children under age 3 watched television daily, while $63 \%$ of 3 - and 4 -year-olds did so. In addition, her survey examined children's use of the Internet, mobile phones, radio, and CDs. Her results showed, for example, that parents indicated that about $38 \%$ of 5- and 6-year-olds 
used the Internet 1-2 times a week, while $70 \%$ of 7 - and 8-year-olds did so. Similarly, older children (7- and 8-year-olds) were more frequent players of digital games, with parents reporting that $75 \%$ of them played 1-2 times a week, whereas only $41 \%$ of the younger children (5- and 6-year-olds) did so. Interestingly, only 15\% of those games were designed for learning. Parents reported a substantial increase in the opportunity to use cellular phones by age: Only $30 \%$ of 5 - and 6-year-olds used mobile phones but $93 \%$ of 7 - and 8 -year-olds did so. Parents reported that $43 \%$ of these older children used mobile phones daily. But listening to recordings or the radio was more equal, with $86 \%$ of 5 - and 6 year-olds and $80 \%$ of 7 - and 8 year-olds listening to them 1-2 times a week. However, listening took place primarily in the car. In regard to reading, $58 \%$ of parents reported reading to their 5- and 6-year-old daily, with $91 \%$ reporting reading at least three times a week. Parent also indicated that their 5- or 6-yearold read on their own or browsed books frequently, with $79 \%$ doing so 6-7 times a week and $21 \%$ once or twice a week. Parents reported that $65 \%$ of 7 - and 8 -year-olds read books 6-7 times a week and 35\% read 3-5 times a week. Reading magazines was slightly less frequent, with $26 \%$ of 7 - and 8-year-olds reading 6-7 times a week, $42 \%$ reading 3-5 times a week, and $32 \%$ reading 1-2 times a week. Based on such findings, Suoninen (2011) concluded that although children regularly used several electronic media, they still read books and magazines.

Many studies reviewed above have focused on Finnish children's use of television and computers. Because family literacy practices may include a variety of print literacy and technoliteracy (Marsh, 2004), we investigated both print and electronic media. In addition, many studies on children have used a case study approach in which the number of children is small (e.g., Koivusalo-Kuusivaara, 2007; Korhonen, 2008). In contrast, we targeted a population large enough to generalize the results. Similar to the current study, Suoninen (2011) also used a larger population and queried parents about young children's print and electronic media use. However, our study differs from Suoninen's by including information on children's emergent literacy knowledge, such as their letter knowledge. Moreover, our populations are different. We surveyed Finnish parents about their preschool (6-year-old) and first-grade (7-year-old) children's home media use in a city that is well known for technology, as well as in the rural areas around the city. Thus, our results provide information on potential differences in the two contexts.

We were interested in learning whether children's practices at home are different among preschool and first-grade children since Finnish first graders are expected to be much more independent than the preschool children in all practical matters (e.g., Strandell \& Forsberg, 2005). As a result, parents may think that they no longer need to read to first graders, letting them take care of their activities in print-literacy or the use of technology on their own. It is also likely that first-grade children have already learned to read, which, in turn, might result in more independent use of media. Therefore, we aimed to shed light on the issue of whether newer technologies are a threat to the use of traditional media.

\section{METHOD}

\section{Participants}

Parents of preschool (6-year-old) and first-grade (7-year-old) children participated in this study. Parents came from either a city or rural areas. The city is currently well known for its 
technology (e.g., Nokia). Earlier, paper mills were big employers in the area. The city has both a multidisciplinary university and a university of applied sciences, as well as other research institutes. The rural areas consist of regions about hundred kilometers north and south of the city. These areas are midsize communities in which people make their living mainly by farming or employment at small enterprises.

Preschools are typically housed in Finnish kindergartens, which provide care for children aged 1 through 6, somewhat analogous to day-care centers in the USA. In this study, the city preschools were housed in kindergarten buildings, as is typical, but in two of the rural cases, the preschools and kindergartens were located within elementary schools. Regardless of their location, all preschools follow the same national curriculum framework.

In this study, the preschool students' parents came from both the city and rural areas. The first-grade students' parents were all from the city.

\section{Questionnaire}

Our questionnaire consisted of 40 questions (see the Appendix) in four categories: 10 items on the children's demographics and family background, 11 about the availability of home media, 11 on how often children used these media and with whom they used them, and 8 questions on children's literacy development.

Our questionnaire drew on the previous work of Marsh et al. (2005), who conducted research with parents of young British children, and who, in turn, drew on similar research in the USA (Rideout, Vandewater, \& Wartella, 2003). However, our questionnaire included questions that dealt with children's literacy development (see the Children's Literacy Development section below), an area that Marsh et al. (2005) did not address. In addition, Marsh and her colleagues studied children aged from birth to 6 years, while we studied children aged 6 and 7. Studying older children allowed us to investigate how parents viewed their children's literacy development.

The survey instrument comprised primarily multiple-choice questions, each with two to 10 answer options. Of the five nonmultiple choice questions, two asked parents the year of their child's birth and the language used at home; the other three addressed the number of newspapers, magazines, and children's magazines subscribed to by the family. All questions resulted in data on a nominal or ordinal scale.

\section{Data Collection}

We surveyed parents in the autumn that their children started preschool (in 2006 or 2007) or first grade (in 2008). We sent the surveys to the home through kindergarten and first-grade teachers and they were returned via teachers in a sealed envelope. In the city, 496 questionnaires were sent to preschool parents and 55\% (275) of them were returned; 564 questionnaires were sent to firstgrade parents, with a return rate of $76 \%$ (427). We sent 250 questionnaires to rural parents of preschool children, with a return rate of $62 \%$ (155). The overall return rate was $65 \%$. The preschool questionnaires were sent to city parents from randomly selected kindergartens in September 2006, and in October 2007 to parents in rural areas surfaced through a network of kindergarten teachers who had participated in an in-service training with the first author. The personal contact with teachers in the rural area may explain the difference in return rate between 
the city (55\%) and rural (62\%) preschool parents. In both cases, however, these response rates are near the $60 \%$ response rate in Marsh et al.'s (2005) study. The questionnaires to first-grade parents were sent October 2008 via the teachers in randomly selected city schools. Because there were two years in between the city preschool and first grade data collection, none of the parents were surveyed twice for the same child. All parents had about 2 weeks to return the questionnaire.

\section{Data Analyses}

The data were analyzed using frequencies and cross tabulations, with chi square $\left(\chi^{2}\right)$ to test significance because the data were either on a nominal or ordinal scale. Because the sample size was large, small differences could have resulted in statistically significant differences that were unwarranted. Therefore, to address this issue and improve reliability, we tested statistical significance by sampling at random a smaller set of the data (see Lenth, 2001). Specifically, we first used the entire data set for cross tabulation and for statistical analysis, but we verified the results by randomly selecting a smaller sample (100 questionnaires from preschool data and 100 from first-grade data) for the same analyses. In our results, we report frequencies in the cross tabulations and statistical significance based on the entire data set, but we used the smaller random sample to verify that the significant effects were reliable.

\section{RESULTS}

Parents of first-grade and preschool children in the city did not differ in educational level (as noted, in the rural area, the survey was sent only to parents of preschoolers). However, there was a difference in educational level between parents in the city and rural areas $\left(\chi^{2}=23.08, p=\right.$ $.000)$, with rural parents having a smaller percentage of advanced degrees $(16 \%)$ than city parents $(34 \%)$. Rural parents were more likely to have vocational education $(37 \%)$ than city parents $(22 \%)$. Nevertheless, many rural parents had college or polytechnic education $(47 \%)$ at about the same rate as city parents $(45 \%)$. The majority $(89 \%)$ of parents who participated were female. Almost all families (98\%) were native Finnish speakers. There were no statistically significant differences in families' level of income in our sample.

We report the results mainly in tables. There were a few statistically significant differences in results between city and rural children, boys and girls, and preschool children and first-graders. Whenever such a difference occurred, we report it in the text.

\section{Home Equipment}

Homes were well equipped, as shown in Table 1. Eighty-eight percent of homes had televisions. Overall, 97\% of homes had a computer: This figure was $99 \%$ in first-graders' homes and $95 \%$ in preschoolers' homes. Internet access was available in $96 \%$ of homes. Console games were less common than televisions or computers, with more first graders $(62 \%)$ than preschool children $(45 \%)$ having console games at home $\left(\chi^{2}=22.57, p=.000\right)$. In addition, more first graders' homes (87\%) than preschool children's homes $(77 \%)$ had a digital camera $\left(\chi^{2}=14.38, p=.000\right)$. 
Table 1. Types of Equipment Present in the Home.

\begin{tabular}{lccc}
\hline Home equipment & Preschoolers & First graders & Average \\
\hline TV & $88 \%$ & $88 \%$ & $88 \%$ \\
Videos & $94 \%$ & $93 \%$ & $94 \%$ \\
Phone/ mobile & $100 \%$ & $100 \%$ & $100 \%$ \\
Radio & $96 \%$ & $93 \%$ & $95 \%$ \\
Stereos & $97 \%$ & $95 \%$ & $96 \%$ \\
Computer/ laptop & $95 \%$ & $99 \%$ & $97 \%$ \\
Console game & $45 \%$ & $62 \%$ & $53 \%$ \\
Video camera & $41 \%$ & $48 \%$ & $44 \%$ \\
Digital camera & $77 \%$ & $87 \%$ & $82 \%$ \\
Internet & $94 \%$ & $97 \%$ & $96 \%$ \\
\hline
\end{tabular}

However, as shown in Table 2, it was unusual for children to have their own computers ( $5 \%$ for both preschool children and first graders). Similarly, only $21 \%$ of preschoolers and first graders had a television in their own room. In addition, the results suggest that most children may receive their own mobile phone when they start school, since $79 \%$ of first graders had one, while only $10 \%$ of preschoolers had a phone $\left(\chi^{2}=402.5, p=.000\right)$.

Table 2. Types of Equipment in a Child's Own or Shared Room.

\begin{tabular}{lccc}
\hline Equipment in own room & Preschoolers & First graders & Average \\
\hline TV & $21 \%$ & $21 \%$ & $21 \%$ \\
Videos & $20 \%$ & $17 \%$ & $19 \%$ \\
Radio & $24 \%$ & $31 \%$ & $28 \%$ \\
Stereos & $41 \%$ & $48 \%$ & $44 \%$ \\
Computer/laptop & $5 \%$ & $5 \%$ & $5 \%$ \\
Internet & $8 \%$ & $11 \%$ & $9 \%$ \\
Console games & $11 \%$ & $17 \%$ & $14 \%$ \\
Own mobile phone & $10 \%$ & $79 \%$ & $45 \%$ \\
\hline
\end{tabular}

\section{Television and Video/DVD Viewing and Listening to the Radio}

Overall, as shown in Table 3, the time spent watching television each day ranged from a small minority $(4 \%)$ of children who watched 3 hours or more to $12 \%$ who did not watch television at all. Most children were in the middle: 45\% watched television 1-2 hours daily while $40 \%$ watched up to an hour daily.

There was a significant difference in preschool children's television watching in the city and rural areas $\left(\chi^{2}=20.27, p=.001\right)$. Specifically, 53\% of rural preschool children watched television one or more hours daily, compared to only $42 \%$ of city preschoolers doing so. Interestingly, more children in the rural area (19\%) than in the city $(10 \%)$ did not watch any television at all. 
Table 3. Time Spent with Various Media.

\begin{tabular}{lcccc}
\hline Hours per day & $>\mathbf{3}$ & $\mathbf{1 - 2}$ & $<\mathbf{1}$ & None \\
\hline TV & $4 \%$ & $45 \%$ & $40 \%$ & $12 \%$ \\
Videos/DVD & $1 \%$ & $22 \%$ & $64 \%$ & $13 \%$ \\
Stereos & $1 \%$ & $6 \%$ & $69 \%$ & $25 \%$ \\
Radio & $1 \%$ & $3 \%$ & $54 \%$ & $42 \%$ \\
Computer & $1 \%$ & $14 \%$ & $67 \%$ & $18 \%$ \\
Console game & $1 \%$ & $8 \%$ & $39 \%$ & $52 \%$ \\
Print media & $3 \%$ & $31 \%$ & $65 \%$ & $1 \%$ \\
\hline
\end{tabular}

Note. Because of rounding, percentages may not equal exactly $100 \%$.

As shown in Table 4, watching videos and DVDs was more popular among the preschool children than first graders: $27 \%$ of preschool children watched videos or DVDs daily or almost daily, whereas $16 \%$ of first graders did so; $52 \%$ of first graders and $42 \%$ of preschool children watched them only once a week or less $\left(\chi^{2}=22.82, p=.000\right)$.

Table 4. Frequency of Using Different Media Activities by Finnish Preschooler (pr) and First Grader (fg).

\begin{tabular}{|c|c|c|c|c|c|c|c|c|c|c|c|c|}
\hline \multirow[t]{2}{*}{$\begin{array}{l}\text { Frequency per } \\
\text { Week }\end{array}$} & \multicolumn{2}{|c|}{ 6-7 days } & \multicolumn{2}{|c|}{ 4-5 days } & \multicolumn{2}{|c|}{ 2-3 days } & \multicolumn{2}{|c|}{ once } & \multicolumn{2}{|c|}{$\begin{array}{r}\text { less than } \\
\text { weekly }\end{array}$} & \multicolumn{2}{|c|}{ never } \\
\hline & $\mathrm{pr}$ & $\mathrm{fg}$ & $\mathrm{pr}$ & $\mathrm{fg}$ & $\mathrm{pr}$ & $f g$ & $\mathrm{pr}$ & $\mathrm{fg}$ & $\mathrm{pr}$ & $\mathrm{fg}$ & $\mathrm{pr}$ & $\mathrm{fg}$ \\
\hline Watches TV & $64 \%$ & $64 \%$ & $19 \%$ & $17 \%$ & $4 \%$ & $6 \%$ & $1 \%$ & $1 \%$ & $2 \%$ & $5 \%$ & $10 \%$ & $7 \%$ \\
\hline Watches videos/DVDs & $8 \%$ & $6 \%$ & $19 \%$ & $10 \%$ & $31 \%$ & $32 \%$ & $20 \%$ & $26 \%$ & $19 \%$ & $25 \%$ & $3 \%$ & $1 \%$ \\
\hline $\begin{array}{l}\text { Listens to the } \\
\text { stereo/CDs }\end{array}$ & $10 \%$ & $6 \%$ & $9 \%$ & $9 \%$ & $22 \%$ & $25 \%$ & $22 \%$ & $15 \%$ & $32 \%$ & $35 \%$ & $5 \%$ & $10 \%$ \\
\hline Listens to the radio & $9 \%$ & $3 \%$ & $8 \%$ & $8 \%$ & $13 \%$ & $16 \%$ & $17 \%$ & $13 \%$ & $35 \%$ & $38 \%$ & $18 \%$ & $22 \%$ \\
\hline Uses computer & $7 \%$ & $13 \%$ & $12 \%$ & $16 \%$ & $24 \%$ & $31 \%$ & $21 \%$ & $16 \%$ & $27 \%$ & $22 \%$ & $8 \%$ & $2 \%$ \\
\hline Plays console games & $1 \%$ & $4 \%$ & $6 \%$ & $10 \%$ & $11 \%$ & $16 \%$ & $9 \%$ & $13 \%$ & $21 \%$ & $23 \%$ & $52 \%$ & $34 \%$ \\
\hline $\begin{array}{l}\text { Reads or scans } \\
\text { books, comics or } \\
\text { magazines }\end{array}$ & $65 \%$ & $66 \%$ & $20 \%$ & $16 \%$ & $10 \%$ & $11 \%$ & $3 \%$ & $5 \%$ & $2 \%$ & $2 \%$ & $0 \%$ & $0 \%$ \\
\hline $\begin{array}{l}\text { Uses cell phone for } \\
\text { playing or calling** }\end{array}$ & $3 \%$ & $32 \%$ & $3 \%$ & $15 \%$ & $9 \%$ & $20 \%$ & $9 \%$ & $8 \%$ & $37 \%$ & $15 \%$ & $39 \%$ & $10 \%$ \\
\hline
\end{tabular}

Note: The cell phone was not necessarily the child's own.

Because of rounding, percentages may not equal exactly $100 \%$.

Listening to the radio was more popular among the preschool children than first graders $\left(\chi^{2}=18.79, p=.002\right)$. For example, $17 \%$ of preschool children listened to the radio daily or almost daily, whereas $11 \%$ of first graders did so. Eighteen percent of preschool children and $22 \%$ of first graders did not listen to the radio at all.

\section{The Use of Computers and Console Games}

As shown in Tables 3 and 4, using the computer was more popular than playing console games. This finding makes sense, considering that $97 \%$ of families had a computer and only $53 \%$ had a 
game console (see Table 1). Although a computer was available in almost every home, Table 3 indicates that only $15 \%$ of children used it one hour or more daily. In addition, $18 \%$ of children did not use computers at all. First graders used computers more often than preschool children: $29 \%$ of first graders used computers at least four times a week but only $20 \%$ of preschool children did so $\left(\chi^{2}=32.36, p=.000\right)$.

First graders also spent more time daily with console games than preschool children. Thirtyone percent of first graders played console games more than half an hour daily, while $18 \%$ of preschoolers did so. For preschool children, 61\% never played console games compared with $43 \%$ of first graders $\left(\chi^{2}=31.36, p=.000\right)$. Girls played console games considerably less frequently than boys, with $67 \%$ of girls and $38 \%$ of boys not playing at all. The daily playing was moderate for most children (see Table 3). It is worth noting that only $1 \%$ of boys (and no girls) played 3 or more hours daily. Thirty-six percent of boys and $12 \%$ of girls played console games half an hour to 2 hours daily $\left(\chi^{2}=88.57, p=.000\right)$.

Some children were also involved in other activities with computers. As shown in Table $5,33 \%$ of children played computer games designed for learning very often or often, while $54 \%$ played other computer games very often or often. For preschool children, 39\% (both in the city and rural areas) played games designed for learning very often compared to $27 \%$ of the first graders $\left(\chi^{2}=34.48, p=.000\right)$. Parents also indicated that $17 \%$ of the children drew with graphic tools very often or often, $58 \%$ sometimes and $24 \%$ never, with girls using graphic tools more frequently than boys. Thirty-two percent of boys but only $17 \%$ of girls did not use graphic tools at all $\left(\chi^{2}=27.91, p=.000\right)$.

Table 5. Use of Computers.

\begin{tabular}{lccccc}
\hline $\begin{array}{l}\text { Working/playing with } \\
\text { computer }\end{array}$ & $\begin{array}{c}\text { Almost } \\
\text { always }\end{array}$ & Often & Sometimes & Rarely & Never \\
\hline Learning games & $12 \%$ & $21 \%$ & $33 \%$ & $20 \%$ & $14 \%$ \\
Other computer games & $11 \%$ & $33 \%$ & $25 \%$ & $15 \%$ & $17 \%$ \\
Music & $0 \%$ & $7 \%$ & $17 \%$ & $20 \%$ & $57 \%$ \\
Movies & $1 \%$ & $5 \%$ & $14 \%$ & $16 \%$ & $64 \%$ \\
Drawing & $2 \%$ & $15 \%$ & $34 \%$ & $24 \%$ & $24 \%$ \\
Surfing the Internet & $2 \%$ & $5 \%$ & $11 \%$ & $15 \%$ & $67 \%$ \\
Writing & $1 \%$ & $2 \%$ & $9 \%$ & $16 \%$ & $72 \%$ \\
Chatting & $0 \%$ & $1 \%$ & $2 \%$ & $3 \%$ & $95 \%$ \\
Email & $0 \%$ & $0 \%$ & $2 \%$ & $3 \%$ & $95 \%$ \\
\hline
\end{tabular}

Note. Because of rounding, percentages may not equal exactly $100 \%$.

Chatting via Messenger was even more rare than graphic tool use, with $95 \%$ of children never doing so while $1 \%$ of the children were frequent users. Similarly, $95 \%$ of children never read or wrote e-mails. Netsurfing was a bit more popular, with $7 \%$ of the children doing it very often or often, $26 \%$ sometimes or seldom, and $67 \%$ never. 


\section{Availability of Print Media}

Despite the increase in electronic media in Finland, it remains customary to subscribe to newspapers. However, newspaper subscriptions differed between the families in the city and those in the rural areas. In the latter locations, $53 \%$ of families subscribed to two or more newspapers, as compared to $24 \%\left(\chi^{2}=60.03, p=.000\right)$ in the city.

Most homes (60\%) have more than 40 children's books, 29\% have 21-40 books, and 11\% have fewer than 20 books. Parents reported the number of other books (not specifically for children) at home as follows: $20 \%$ had more than 200 books, $26 \%$ had $81-200,41 \%$ had $21-80$, and $13 \%$ fewer than 20 books. There were more books in city homes ( $48 \%$ reported more than 100 books) than in homes in the rural area $\left(28 \%\right.$ reported more than 100 books; $\left.\chi^{2}=21.62, p=.001\right)$. Fortyeight percent of parents in rural areas reported visiting libraries at least 2-3 times a month compared to $32 \%$ of city parents $\left(\chi^{2}=11.40, p=.022\right)$. Similarly, preschool children $(47 \%)$ in rural areas visited libraries more often than city preschool children $\left(23 \% ; \chi^{2}=28.46, p=.000\right)$.

\section{Use of Print Media}

As indicated in Table 3, more children (34\%) spent at least 1 hour per day with print mediasuch as reading books or comics in children's magazines - than with either computers $(15 \%)$ or playing console games (9\%). Only television watching, with $49 \%$ viewing at least an hour daily, was more frequent than time spent with books and other print materials. Although taken together, nonprint media certainly compete with print media, nevertheless $85 \%$ of preschool children were engaged in reading books, magazines, or comic strips 4-7 days a week (see Table 4). Typically, this practice took place with their parents. In fact, as reported in Table 6, most parents of both preschoolers and first graders read bedtime stories to their children. However, there was a statistically significant difference between preschool and first grade bedtime reading, with $70 \%$ of preschool children's parents reading very often or often while $58 \%$ of first graders' parents did so $\left(\chi^{2}=15.93, p=.001\right)$. It is important to note that, according to the parents, $21 \%$ of preschool children were able to read by themselves, while $77 \%$ of the first-grade children were able to read. Despite the fact that most first graders had learned to read, most parents reported still regularly reading bedtime stories to them.

Table 6. Parents Reading Bedtime Stories.

\begin{tabular}{lcccc}
\hline & Very often & Often & Sometimes & Never \\
\hline Preschoolers & $50 \%$ & $20 \%$ & $26 \%$ & $4 \%$ \\
First graders & $41 \%$ & $17 \%$ & $33 \%$ & $9 \%$ \\
Average & $45 \%$ & $19 \%$ & $30 \%$ & $6 \%$ \\
\hline
\end{tabular}

According to the survey, $88 \%$ of the parents started reading to their children before the child was a year old. But there was a difference according to the level of the parents' education $\left(\chi^{2}=50.44, p=.000\right)$. Parents with a higher level of education were more likely to start reading early. For example, while $45 \%$ of parents with vocational education or less began reading to their children before 6 months of age, $66 \%$ of those with advanced degrees did so. 


\section{Children's Literacy Development}

We included questions about children's emerging literacy to investigate how actively children were involved in print media in their environment. For example, these questions addressed how actively children asked questions about print, whether they showed interest in print in various media contexts, to what extent they recognized letters and words, whether they attempted to write and were interested in writing, and whether they were able to read. We also examined whether there were differences between boys and girls. We focus here on preschool children because, as noted, parents reported that $77 \%$ of the first graders were already reading conventionally.

The results for preschool children indicated that only 7\% had not demonstrated interest in print by asking questions about what is written (e.g., on television, shop windows, signs) whereas $37 \%$ asked questions and $56 \%$ of the children were actively trying to recognize letters and words. In fact, parents reported that $72 \%$ of the children were able to recognize all the letters at the beginning of their preschool year and only $2 \%$ did not recognize any. As shown in Table 7 , parents indicated that the most interesting contexts for reading attempts were books, magazines, and comics, with $49 \%$ of the children very interested in recognizing words in them and only $1 \%$ not showing any interest. Logos, such as those in shops, appeared to be very interesting for $37 \%$ of the children. As might be expected, the majority of children showed at least some interest in these logos. Almost equally interesting contexts were texts in the children's home environment. Namely, $32 \%$ of the children attempted to read texts such as those on milk cartons while only $5 \%$ of children were not interested in reading them. Surprisingly, texts on television were a much less interesting context for the literacy activity, with only $11 \%$ of children very interested in recognizing these texts and $25 \%$ not interested at all.

Similarly, writing attempts were frequent, with $53 \%$ of parents reporting that their children were either writing or pretending to write daily. In addition, when asked if their child was interestedin writing, parents noted that $49 \%$ of children were very interested in writing activities. However, there was a statistically significant gender difference in interests, with $66 \%$ of the girls interested in writing but only $34 \%$ of the boys demonstrating similar interest $(\chi 2=53.83, p=$ .000). Moreover, a similar statistically significant difference was found between the frequencies of writing activities: $70 \%$ of the girls wrote daily but only $39 \%$ of the boys did so $(\chi 2=42.62$,

Table 7. Preschooler Interest in Finding Out About the Printed Text in Various Situations.

\begin{tabular}{lccccc}
\hline $\begin{array}{l}\text { How interested the } \\
\text { preschooler is in }\end{array}$ & $\begin{array}{c}\text { Very } \\
\text { interested }\end{array}$ & $\begin{array}{c}\text { Quite } \\
\text { interested }\end{array}$ & $\begin{array}{c}\text { A bit } \\
\text { interested }\end{array}$ & $\begin{array}{c}\text { Not } \\
\text { interested }\end{array}$ & $\begin{array}{c}\text { Don't } \\
\text { know }\end{array}$ \\
\hline Text on television & $11 \%$ & $24 \%$ & $32 \%$ & $25 \%$ & $8 \%$ \\
Texts of different magazines & $24 \%$ & $35 \%$ & $32 \%$ & $9 \%$ & $0 \%$ \\
Ads & $18 \%$ & $30 \%$ & $34 \%$ & $17 \%$ & $1 \%$ \\
Shop signs, road signs, etc. & $37 \%$ & $34 \%$ & $26 \%$ & $3 \%$ & $0 \%$ \\
$\begin{array}{l}\text { Other texts at home (e.g., on a } \\
\text { milk carton) }\end{array}$ & $32 \%$ & $39 \%$ & $24 \%$ & $5 \%$ & $0 \%$ \\
$\begin{array}{l}\text { When reading a book, comic } \\
\text { book or a magazine }\end{array}$ & $49 \%$ & $34 \%$ & $16 \%$ & $1 \%$ & $0 \%$ \\
\hline
\end{tabular}

Note. Because of rounding, percentages may not equal exactly $100 \%$. 
$p=.000)$. Despite these statistically significant differences in interests and the frequencies in their attempts, there was no difference between boys' and girls' literacy development, with 22\% of the girls and $20 \%$ boys being able to read in preschool.

\section{DISCUSSION}

Our findings indicate that Finnish preschool and first-grade children are quite frequent media users, and homes provide them with an environment that includes traditional media as well as newer technologies. Interestingly, parents reported more computers than televisions in their homes. Additionally, our data indicate that young Finnish children have televisions in their own rooms less often than their British or American peers. Marsh et al. (2005) reported that $29 \%$ of the British children aged 0 to 6 years in their study had their own televisions and Common Sense Media (2011) reported that $42 \%$ of 0 - to 8 -year-old children in the USA had a television. In contrast, we found that only $21 \%$ of Finnish children have their own televisions, which differs from Suoninen (2011), who reported that only 10\% of children had a television in their own room. Similar to results from case studies (e.g., Valkonen et al., 2005) and Suoninen's survey (2011), our results indicate that the time spent watching television varied. Parents reported that $40 \%$ of the children watched television less than an hour a day and $12 \%$ of the children did not watch at all. A very small minority of preschool-age children $(0.4 \%$ in the city and none in the rural areas) watched television more than 4 hours daily. The finding that there are more computers than televisions in homes, as well as variation in time spent watching television, could possibly be explained by the fact that the area has a large population of a religious group that does not accept television but does allow videos/DVDs, computers and the Internet. However, this possibility needs to be explored.

Based on our findings as well as previous research, playing electronic games and computerbased games is a common activity in Finland. Interestingly, our results indicate that preschool children play more games designed for learning while first graders play more entertainment games. This finding corresponds to Suoninen's (2011) finding that learning games were not as popular as entertainment games with first graders. Our results indicate that boys were more frequent game players than girls, as is evident in other studies as well (Ermi et al., 2005; Matikkala \& Lahikainen, 2005; Suoninen, 2011). Some parents think that computer gaming is beneficial for children's learning (see Suoninen, 2011). However, this view might reflect an overemphasis on the potential benefits: A child's technical skills do not necessarily translate into learning skills in information and communication technology (ICT) contexts.

Finnish parents have not been ambitious to teach literacy to their children before school (Karvonen, 2005). However, several games have been designed to help prepare children for school by teaching, for instance, letters and their sounds. Parents may think that these games are useful specifically before school, but presume the school will take responsibility for teaching once the child enters first grade.

Parents noted that a high percentage of children could read at the start of first grade, indicating that children have learned to read during their preschool year or before. Our findings suggest that many activities at home can spark children's curiosity about learning literacy, such as using environmental print as a context for learning letters and other concepts of print. 
Furthermore, our findings indicate that Finnish homes still reflect a reading culture that values print media. Although watching television is a common and frequent activity, especially among preschoolers, children also engage in reading several days of a week. The use of libraries is also frequent, as is the practice of reading bedtime stories. However, parents do not read as frequently to their first graders as to their preschool children. This finding might reflect some parents' belief that children do not need to be read to once they learn to read themselves.

The decrease in frequency of reading to first graders may be related to notion of children being expected to be independent at a young age in Finland. This expectation has been addressed in the media with regard to children staying at home alone after school, beginning in the first grade (Strandell \& Forsberg, 2005). Perhaps being home alone after school is the reason for our finding a dramatic increase in the number of children with their own mobile phones, as preschoolers move to first grade. A similar finding was also observed in Suoninen's (2011) study. First graders need mobile phones to call their parents while they are on their own at home or in the neighborhood after school before their parents come from work.

Importantly, our results support the claim that newer technologies have not harmed literacy development, as has been debated (Schmidt et al., 2006), but may even support it (e.g., Karchmer et al., 2002). Literacy skill was found to develop well, with $77 \%$ of parents reporting that their first-grade child was able to read before the start of school. Moreover, the parents' reports showed no difference in the percentage of boys and girls who could read at the beginning of their preschool year, even though girls showed more interest in writing and were more engaged in writing activities than boys, while boys played more console and computerbased games (which may have included learning games). This lack of gender distinction at the beginning of the preschool year may indicate that involvement in print literacy is not more powerful than other media environments in learning to read. In fact, electronic media may motivate some children even more than printed texts. Such motivation, in turn, affords opportunities for children to learn literacy, provided that electronic media include print in a meaningful way from a child's point of view. But to explore this issue more ethnographic research is needed to investigate processes occurring in children's activities with media in formal and informal environments.

Evidence indicates, however, that Finnish first-grade classroom instruction has not taken into account children's developing competencies with newer technologies (Korkeamäki \& Dreher, 2011), even though the national core curriculum for first and second grade states that (a) instruction should continue the learning that has begun at home, and (b) children's reading and writing skills, including media literacy and skills in ICTs, should be developed (National Board of Education, 2004). Moreover, even the use of children's trade books is rare in firstgrade classrooms (Korkeamäki \& Dreher, 2011). Preschool classrooms are even less well equipped with technology, such as computers and access to the Internet, than the classrooms in schools. Therefore, children's home environments are the primary source for learning media literacy skills. However, new technologies offer abundant resources that could enrich the curriculum so that it better matches children's interests and lives (e.g., Marsh, 2008). Also, the use of media and popular culture affords opportunities for facilitating children's development as critical users of media. Indeed, some children are very competent producers of digital texts and have posted their texts on the Internet before they enter school.

Our findings and the findings of other Finnish studies about children as frequent users of new technologies correspond to similar results in other countries, such as Britain (Ofcom, 
2010) and the USA (Blanchard \& Moore, 2010; Common Sense Media, 2011). However, despite such findings, some have argued that teachers do not take advantage of the literacy and technological skills young children bring to school with them (see Knobel, 2006). Researchers have suggested that since print-based texts have changed to screen-based, instruction should also reflect this change (e.g., Kress, 2003; Marsh, 2009). Because they involve new technologies (e.g., computers, console games, and mobile phones), multimodal texts and techno-literacy practices (Marsh, 2004) challenge teachers, even though words and letters on screen continue to be important (Marsh, 2009). Teachers and teacher educators need to address this challenge with more classroom research that investigates the usefulness of techno-literacy and how it might support the development of print literacy.

We recognize the limitations of our research. First, studies that examine media use are subject to the rapidly changing technology environment, and this study is no exception. New forms of technology have already emerged since we collected our data. For example, this study could not have specifically addressed forms of media that have appeared or increased in popularity after the data were collected (e.g., tablet computers, increasingly smarter phones). Although newer technologies could affect the results, a survey of Finnish children conducted after ours showed similar results (Suoninen, 2011), thus supporting our findings. Furthermore, the findings of Common Sense Media (2011) show that the newer technologies are not yet very common with young US children and that the time they spend with these devices is still very small compared to other media.

Another possible limitation of this study is that city preschool parents had a lower response rate $(55 \%)$ compared to rural preschool parents $(62 \%)$. As noted earlier, however, response rates for both groups were similar to the response rate in Marsh et al.'s (2005) study. In addition, although differential response rates could have affected the results, the evidence indicates few differences between rural and city results, suggesting that media culture is similar in both the city and rural areas.

\section{CONCLUSION}

Our study confirms the findings of several earlier case studies. But more importantly, our findings from 2006-2008 data parallel those of Suoninen's (2011) study with 2010 data that used similar methods. Because many of the items in Suoninen's and our surveys were quite similar, these two large-scale studies confirm that young Finnish children's use of technology at home is very frequent. Similar results have been found in studies in several countries (e.g., Common Sense Media, 2011; Ofcom, 2010). This trend, thus, presents a challenge to preschools and schools: Evidence indicates that instructional practices typically do not take advantage of young children's developing knowledge of diverse technologies (e.g., Korkeamäki \& Dreher, 2011).

In addition to providing converging evidence of children's media use at home, our study also addressed children's literacy learning, an area that was not part of Suoninen's study. Our findings suggest that technology does not harm literacy development. However, we need more studies in relation to learning literacy and the use of technologies, specifically focusing on learning literacy both in formal and informal settings. In particular, research is needed on how teachers can build on the knowledge that many of today's young children already possess when they enter school. 


\section{REFERENCES}

Blanchard, J., \& Moore, T. (2010). The digital world of young children: Impact on emergent literacy (White paper). Retrieved from http://www.pearsonfoundation.org/downloads/EmergentLiteracy-WhitePaper.pdf

Common Sense Media. (2011). Zero to eight: Children's media use in America. Retrieved from http://www.commonsensemedia.org/research

Ermi, L., Mäyrä, F., \& Heliö, S. (2005). Digitaaliset lelut ja maailmat: Pelaamisen vetovoima [Digital toys and worlds: The power of playing]. In A. R. Lahikainen, P. Hietala, T. Inkinen, M. Kangassalo, R. Kivimäki, \& F. Mäyrä (Eds.), Lapsuus mediamaailmassa. Näkökulmia lasten tietoyhteiskuntaan [Childhood in media world: Views on children's information society] (pp. 110-128). Helsinki, Finland: Gaudeamus.

Hirvonen, R. (2012). Lasten mediakäytöt ja kotien mediakasvatus lasten kertomina [Children's use of media and media education at home as told by children]. In S. Pääjärvi (Ed.), Lasten mediabarometri 2011. 7-11vuotiaiden lasten mediakäytäntö ja kokemukset mediakasvatuksesta [Children's media barometer in 2011. 7-11- year- old children's use of media and their experiences in media education] (Publication 1/2012; pp. 17-53). Helsinki, Finland: Finnish Society of Media Education.

Karchmer, R. A., Mallette, M. H., \& Leu, D. J., Jr. (2002). Early literacy in the digital age: Moving from a singular book literacy to the multiple literacies of networked information and communication technologies. In D. M. Barone \& L. M. Morrow (Eds.), Literacy and young children: Research based practices (pp. 175-194). New York, NY, USA: Guilford.

Karvonen, P. (2005). Päiväkotilasten lukuleikit. Lukutaidon ja lukemistietoisuuden kehittyminen interventiotutkimuksessa [Reading games for children in daycare centers: The development of reading ability and reading awareness in an intervention Study] (Doctoral dissertation; Studies in Education, Psychology and Social Research 270). Jyväskylä, Finland: University of Jyväskylä..

Knobel, M. (2006). Technokids, Koala trouble and Pokemon: Literacy, new technology and popular culture in children's everyday lives. In J. Marsh \& E. Millard (Eds.), Popular literacies, childhood and schooling (pp. 11-28). London, England: Routledge.

Koivusalo-Kuusivaara, R. (2007). Lapset, media ja symbolinen vuorovaikutus: Suomalaisten, saksalaisten ja englantilaisten lasten mediasuhteen tarkastelua [Children, media and symbolic interaction: Examination of relation of media among Finnish, German and British children]. (Doctoral dissertation; Communication Publications 14). Helsinki, Finland: University of Helsinki.

Korhonen, P. (2008). Lasten TV-ohjelmiin liittyvät pelot, painajaisunet ja pelonhallinta [Children's fears, nightmares and controlling fear connected to TV programs]. (Doctoral dissertation; Acta Universitatis Tamperensis 1332). Tampere, Finland: University of Tampere.

Korkeamäki, R.-L., \& Dreher, M. J. (2011). Early literacy practices and the Finnish national core curriculum. Journal of Curriculum Studies, 43(1), 109-137.

Kress, G. (2003). Literacy in the new media age. London, England: Routledge.

Lappalainen, H. (2008). On annettu hyviä numeroita. Perusopetuksen 6. Vuosiluokan suorittaneiden äidinkielen ja kirjallisuuden oppimistulosten arviointi 2007 [Good grades have been given: The evaluation of achievement in mother tongue and literature of students who have passed the sixth grade]. Helsinki, Finland: National Board of Education.

Lenth, R. V. (2001). Some practical guidelines for effective sample-size determination. The American Statistician, 55(3), 187-193.

Marsh, J. (2004). The techno-literacy practices of young children. Journal of Early Childhood Research, 2(1), 51-66.

Marsh, J. (2008). Popular culture in the language arts classrooms. In J. Flood, S. B. Heath, \& D. Lapp (Eds.), Handbook of research on teaching literacy through the communicative and visual arts (Vol. 2; pp. 529536). New York, NY, USA: Erlbaum.

Marsh, J. (2009). Productive pedagogies; Play, creativity and digital cultures in the classroom. In R. Willet, M. Robinson, \& J. Marsh (Eds.), Play, creativity and digital cultures (pp. 200-218). London, England: Routledge. 
Marsh, J., Brooks, G., Hughes, J., Ritchie, L., Robert, S., \& Wright, K. (2005). Digital beginnings: Young children's use of popular culture, media and new technologies. Retrieved from http://www.digitalbeginnings.shef.ac.uk/final-report.htm

Matikkala, U., \& Lahikainen, A. R. (2005). Pelit, tietokoneet ja kännykkä lasten sosiaalisissa suhteissa [Games, computers and mobile phones in children's social relationships]. In A. R. Lahikainen, P. Hietala, T. Inkinen, M. Kangassalo, R. Kivimäki, \& F. Mäyrä (Eds.), Lapsuus mediamaailmassa. Näkökulmia lasten tietoyhteiskuntaan [Childhood in media world: Views on children's information society] (pp. 92-109). Helsinki, Finland: Gaudeamus.

National Board of Education. (2004). Core curriculum for basic education. Helsinki, Finland: Board of Education.

Neuman, S. (1988). The displacement effect: Assessing the relation between television viewing and reading performance. Reading Research Quarterly, 23, 414-441.

Ofcom. (2010). UK children's media literacy. Retrieved from http://stakeholders.ofcom.org.uk/binaries/research/media-literacy/ukchildrensmll.pdf

Oinas-Kukkonen, H., \& Kurki, H. (2009). Internet through the eyes of 11-year-old children: First-hand experiences for the technological environment children live in. Human Technology: An Interdisciplinary Journal on Humans in ICT Environments, 5(2), 146-162.

Rathbun, A. H., \& West, J. (2003). Young children's access to computers in the home and at school in 1999 and 2000 (NCES 2003-036). Washington, DC, USA: U.S. Department of Education, National Center for Education Statistics.

Rideout, V. J., Foehr, U. G., \& Roberts, D. F. (2010). Generation $M^{2}$ : Media in the lives of 8-to 18-year-olds. Retrieved from http://www.kff.org/entmedia/upload/8010.pdf

Rideout, V. J., \& Hamel, E. (2006). The media family: Electronic media in the lives of infants, toddlers, preschoolers and their parents. Retrieved from http://www.kff.org/entmedia/7500.cfm

Rideout, V. J., Vandewater, E. A., \& Wartella, E. A. (2003). Zero to six: Electronic media in the lives of infants, toddlers and preschoolers. Retrieved from http://www.kff.org/entmedia/3378.cfm

Sauri, T. (2007). Sanomalehdet pystyvät vastaamaan ajan haasteisiin [Newspapers are able to respond to the challenges of the times]. Hyvinvointi Katsaus, 2, 28-30.

Schmidt, M. E., Bickham, D., King, B., Slaby, R., Branner, A. C., \& Rich, M. (2006, January). The effects of electronic media on children ages zero to six: A history of research (Issue Brief). Retrieved from http://www.kff.org/entmedia/7239.cfm

Spadaro, R. (2002, April). Europeans' participation in cultural activities: A Eurobarometer survey carried out at the request of the European Commission, Eurostat (Executive Summary). Retrieved from http://ec.europa.eu/culture/pdf/doc967_en.pdf

Strandell, H., \& Forsberg, H. (2005). Kohti kurinalaista lapsuutta: Kysymys pienten koululaisten iltapäivän uudelleen määrittelystä [Towards disciplined childhood: The question of redefining young primary school children's afternoons]. Yhteiskuntapolitiikka, 70(6), 610-623.

Suoninen, A. (2011). Children's media use as described by their parents. In S. Kotilainen (Ed.), Children's media barometer 2010: The use of media among 0-8-year-olds in Finland (pp. 9-14). Helsinki, Finland: Finnish Society on Media Education. Retrieved from http://www.mediaeducation.fi/publications/ISBN978952-99964-7-6.pdf

Teale, W., \& Sulzby, E. (1989). Introduction: Emergent literacy as a perspective for examining how young children become writers and readers. In W. Teale \& E. Sulzby (Eds.), Emergent literacy: Writing and reading (pp. vii-xxv). Norwood, NJ, USA: Ablex.

Uusitalo, N., Vehmas, S., \& Kupiainen, R. (2011). Naamatusten verkossa- Lasten ja nuorten mediaympäristön muutos, osa 2 [Face to face in the net: The change in children's and youngsters' media environment, Part 2]. Retrieved from http://tampub.uta.fi/N/naamatusten_verkossa_2011.pdf

Valkonen, S., Pennonen, M., \& Lahikainen, A. R. (2005). Televisio pienten lasten arjessa [Television in the life of young children]. In A. R. Lahikainen, P. Hietala, T. Inkinen, M. Kangassalo, R. Kivimäki, \& F. Mäyrä 
(Eds.), Lapsuus mediamaailmassa: Näkökulmia lasten tietoyhteiskuntaan [Childhood in media world: Views on children's information society] (pp. 54-91). Helsinki, Finland: Gaudeamus.

Vandewater, E. A., Rideout, V. J., Wartella, E. A., Huang, X., Lee, J. H., \& Shim, M. S. (2007). Digital childhood: Electronic media and technology use among infants, toddlers, and preschoolers. Pediatrics, 119(5), 1006-1015.

Yaden, D. B., Jr., Rowe, D. W., \& MacGillivray, L. (2000). Emergent literacy: A matter (polyphony) of perspectives. In M. L. Kamil, P. B. Mosenthal, P. D. Pearson, \& R. Barr (Eds.), Handbook of reading research (Vol. 3; pp. 425-454). London, England: LEA.

YIPPEE 2008 / Sanoma Magazines Finland (TNS Gallup \& Research International Finland). (2008, February 2). Perheillä yhteistä aikaa ja sääntöjä; lapset toisaalta itsenäisiä kuluttajia (Media release). Retrieved November 1, 2012, from http://www.sanomamagazines.fi/yritysinfo/mediamateriaali/ajankohtaista/2008/art253-Perheilla-yhteistaaikaa-ja-saantoja---lapset-toisaalta-itsenaisia-kuluttajia.html

\section{Authors' Note}

All correspondence should be addressed to

Riitta-Liisa Korkeamäki

Faculty of Education

University of Oulu

P.O. Box 2000

FIN-90014 University of Oulu

Finland

riitta-liisa.korkeamaki@oulu.fi

Human Technology: An Interdisciplinary Journal on Humans in ICT Environments ISSN 1795-6889

www.humantechnology.jyu.fi 


\section{Appendix}

\section{QUESTIONNAIRE ABOUT PRESCHOOL AGE CHILDREN'S USE OF MEDIA ${ }^{1}$}

Background questions

1. Your gender
1. male
2. female

2. Gender of your preschool age child
1. boy
2. girl

3. Birth year of your preschool age child

4. Your preschool age child has

1. a younger sibling / younger siblings

2. an older sibling / older siblings

3. both a younger sibling / siblings and an older sibling / siblings

4. preschooler is the only child

5. Your professional education (if you are a student, choose your education according to your upcoming degree)

1. no professional education

2. professional course or courses

3. vocational school

4. institute level education

5. polytechnic degree

6. academic qualification

6. Professional education of your spouse or partner (if he/she is a student, choose his/her education according to the upcoming degree)
1. no professional education
2. professional course or courses
3. vocational school
4. institute level education
5. polytechnic degree
6. academic qualification

7. Which of the following options describes your work situation best?

1. day job

2. shift work

3. part-time job

4. not working

8. Which of the following options describes your spouse or partner's work situation best?
1. day job
2. shift work
3. part-time job
4. not working

\footnotetext{
${ }^{1}$ The survey was conducted in Finnish, and translated here by the researchers. The questionnaire for first graders was identical except that preschool was replaced by first grade.
} 
9. In your opinion, your economic situation is
1. very good
2. good
3. satisfactory
4. difficult
5. very difficult

10. What language is primarily spoken in your family?

The following questions are related to the media equipment in your home.

11. Which of the following equipment is found at your home? You may select as many choices as needed.

Take into account only the equipment that is working and is in use.
1. television
2. VCR / DVD
3. telephone (also cell phones)
4. radio
5. stereo / CD player or tape player
6. computer (also laptops)
7. game console (PlayStation, X-Box, etc.)
8. video camera / digital video camera meant for shooting videos
9. digital camera
10. none of the above

12. Do any of your home computers have Internet connection?
1. yes
2. no

13. Which of the following equipment does your preschool age child have in his/her own or a shared room? You may select as many choices as needed.
1. television
2. VCR / DVD
3. radio
4. stereo / CD player or tape player
5. computer without Internet connection
6. computer with Internet connection
7. game console (PlayStation, X-Box, etc.)
8. none of the above

14. Does your child have his/her own cell phone?
1. yes
2. no

15. How many of the following does your preschool age child own or share with siblings? Choose the best answer for each row.

$\begin{array}{lcccccc} & \mathbf{0} & \mathbf{1 - 1 0} & \mathbf{1 1 - 2 0} & \mathbf{2 1 - 3 0} & \mathbf{3 1 - 4 0} & \text { over } 40 \\ \begin{array}{l}\text { books (picture books, } \\ \begin{array}{l}\text { storybooks, nonfiction } \\ \text { books, coloring books, etc.) }\end{array}\end{array} & 1 & 2 & 3 & 4 & 5 & 6 \\ \begin{array}{l}\text { videos / DVDs computer or } \\ \text { console games }\end{array} & 1 & 2 & 3 & 4 & 5 & 6 \\ \begin{array}{l}\text { music recordings } \\ \text { fairy tale recordings }\end{array} & 1 & 2 & 3 & 4 & 5 & 6 \\ & 1 & 2 & 3 & 4 & 5 & 6\end{array}$

16. How many other books altogether are there in your house? (children's books not included)
1. $0-20$
2. $21-50$
3. $51-80$
4. $81-100$
5.101-150
6. $151-200$ 7. more than 200 
17. How many newspaper subscriptions are delivered to your home at the moment? pcs.

18. How many magazine subscriptions for adults are delivered to your home at the moment? pcs.

19. Are there some magazine subscriptions for your child? (also magazine subscriptions for siblings to share?) How many? pcs.

20. How often do you buy newspapers or magazines as newsstand copies?
1. almost every day
2. 2-4 times a week
3. about once a week
4. less than once a week
5. never

21. How many computer games designed to support learning do you have in your household?
1. 11 or more
2. $5-10$
3. $2-4$
4. 1
5. don't know
6. none

The following questions are related to your preschool age child's use of media

22. How often does your child do the following activities? Choose one option for each row.

\begin{tabular}{|c|c|c|c|c|c|c|}
\hline & $\begin{array}{l}\text { 6-7 days } \\
\text { a week }\end{array}$ & $\begin{array}{l}\text { 4-5 days } \\
\text { a week }\end{array}$ & $\begin{array}{l}\text { 2-3 days } \\
\text { a week }\end{array}$ & $\begin{array}{c}\text { once a } \\
\text { week }\end{array}$ & $\begin{array}{l}\text { less than } \\
\text { once a week }\end{array}$ & never \\
\hline watches TV & 1 & 2 & 3 & 4 & 5 & 6 \\
\hline watches video / DVD & 1 & 2 & 3 & 4 & 5 & 6 \\
\hline listens to the stereo & 1 & 2 & 3 & 4 & 5 & 6 \\
\hline listens to the radio & 1 & 2 & 3 & 4 & 5 & 6 \\
\hline uses the computer & 1 & 2 & 3 & 4 & 5 & 6 \\
\hline $\begin{array}{l}\text { plays with the game } \\
\text { console }\end{array}$ & 1 & 2 & 3 & 4 & 5 & 6 \\
\hline $\begin{array}{l}\text { reads or scans books, } \\
\text { comics or magazines }\end{array}$ & 1 & 2 & 3 & 4 & 5 & 6 \\
\hline $\begin{array}{l}\text { uses cell phone (e.g., for } \\
\text { playing or calling; not } \\
\text { necessarily his/her own) }\end{array}$ & 1 & 2 & 3 & 4 & 5 & 6 \\
\hline
\end{tabular}

23. How much time, on average, does your preschool age child use the following activities per day? Choose one option for each row.

watching TV

watching video / DVD listening to the stereo listening to the radio using the computer playing with a game console scanning or reading books, comics or magazines more than 3-4 hours 1-2 hours from half an less than never 4 hours

$\begin{array}{lll}1 & 2 & 3 \\ 1 & 2 & 3 \\ 1 & 2 & 3 \\ 1 & 2 & 3 \\ 1 & 2 & 3 \\ 1 & 2 & 3 \\ 1 & 2 & 3\end{array}$
hour to an hour half an hour

$\begin{array}{lll}4 & 5 & 6 \\ 4 & 5 & 6 \\ 4 & 5 & 6 \\ 4 & 5 & 6 \\ 4 & 5 & 6 \\ 4 & 5 & 6 \\ 4 & 5 & 6\end{array}$


24. Books, magazines, comic books, etc., are read to the child ...
1. many times a day
2. at least once a day
3. many times a week
4. about once a week or less
5. hardly ever

25. How old was your child when you began to read to or look at picture books with him/her?
1. under 6 months old
2. 6 months -1 year old
3. 1-2 years old
4. 2-3 years old
5. 3-4 years old
6. 5-6 years old
7. don't know
8. child is not being read to

26. Your child is read to ...

$\begin{array}{lcccc} & \begin{array}{c}\text { almost } \\ \text { always }\end{array} & \text { often } & \text { sometimes } & \text { never } \\ \text { when going to bed } & 1 & 2 & 3 & 4 \\ \text { when he/she wants and some adult has time } & 1 & 2 & 3 & 4 \\ \text { in other situations, when? } & 1 & 2 & 3 & 4\end{array}$

\section{How often do you go to the library?}

$\begin{array}{lccccc} & \begin{array}{c}\text { once or } \\ \text { more a week }\end{array} & \begin{array}{c}\mathbf{2 - 3} \text { times a } \\ \text { month }\end{array} & \begin{array}{c}\text { once a } \\ \text { month }\end{array} & \text { very rarely } & \text { never } \\ \text { father / mother } & 1 & 2 & 3 & 4 & 5 \\ \text { preschool age child } & 1 & 2 & 3 & 4 & 5\end{array}$

28. What do you borrow from the library for your preschool age child?

$\begin{array}{lccccc} & \text { almost always } & \text { often } & \text { sometimes } & \text { rarely } & \text { never } \\ \text { books } & 1 & 2 & 3 & 4 & 5 \\ \text { magazines } & 1 & 2 & 3 & 4 & 5 \\ \text { videos / DVDs } & 1 & 2 & 3 & 4 & 5 \\ \text { computer or } & 1 & 2 & 3 & 4 & 5 \\ \text { console games } & 1 & 2 & 3 & 4 & 5 \\ \text { fairy tale recordings } & 1 & 2 & 3 & 4 & 5 \\ \text { music } & 1 & & \end{array}$


29. How often does one of the parents do the following activities together with your preschool age child?

\begin{tabular}{|c|c|c|c|c|c|}
\hline & every day & $\begin{array}{c}\text { 2-6 times a } \\
\text { week }\end{array}$ & once a week & $\begin{array}{c}\text { less than } \\
\text { once a week }\end{array}$ & never \\
\hline watches TV & 1 & 2 & 3 & 4 & 5 \\
\hline watches video / DVD & 1 & 2 & 3 & 4 & 5 \\
\hline $\begin{array}{l}\text { uses the computer or } \\
\text { game console }\end{array}$ & 1 & 2 & 3 & 4 & 5 \\
\hline $\begin{array}{l}\text { reads a book, comics } \\
\text { or magazines }\end{array}$ & 1 & 2 & 3 & 4 & 5 \\
\hline $\begin{array}{l}\text { listens to music or } \\
\text { fairy tale recordings }\end{array}$ & 1 & 2 & 3 & 4 & 5 \\
\hline listens to the radio & 1 & 2 & 3 & 4 & 5 \\
\hline $\begin{array}{l}\text { participates in his / } \\
\text { her games }\end{array}$ & 1 & 2 & 3 & 4 & 5 \\
\hline $\begin{array}{l}\text { participates in his } \\
\text { /her hobby activities }\end{array}$ & 1 & 2 & 3 & 4 & 5 \\
\hline
\end{tabular}

30. With whom does your child usually

watch TV

watch video / DVD

listen to music or fairy tale recordings

listen to the radio

play with game

consoles

use the computer

surf online

$\begin{array}{cc}\text { with } & \text { with } \\ \text { friends } & \text { siblings }\end{array}$

1

1

1

1

1

1

$\begin{array}{ccc}\begin{array}{c}\text { with } \\ \text { parents }\end{array} & \begin{array}{c}\text { with someone } \\ \text { else }\end{array} & \text { alone } \\ 3 & 4 & 5 \\ 3 & 4 & 5 \\ 3 & 4 & 5 \\ 3 & 4 & 5 \\ 3 & 4 & 5 \\ 3 & 4 & 5 \\ 3 & 4 & 5\end{array}$

doesn't do this

6

6

6

6

6

6

6

31. What does your child do with the computer?

plays computer games designed to support learning

plays other computer games

listens to music

watches movies

draws with a drawing program

surfs on the Internet

uses a word processor

discusses with friends (e.g., in Messenger)

reads and writes emails

something else, what?

$\begin{array}{ccccc}\begin{array}{c}\text { almost } \\ \text { always }\end{array} & \text { often } & \text { sometimes } & \text { rarely } & \text { never } \\ 1 & 2 & 3 & 4 & 5 \\ 1 & 2 & 3 & 4 & 5 \\ 1 & 2 & 3 & 4 & 5 \\ 1 & 2 & 3 & 4 & 5 \\ 1 & 2 & 3 & 4 & 5 \\ 1 & 2 & 3 & 4 & 5 \\ 1 & 2 & 3 & 4 & 5 \\ 1 & 2 & 3 & 4 & 5 \\ 1 & 2 & 3 & 4 & 5 \\ 1 & 2 & 3 & 4 & 5\end{array}$


32. Think back; at what age did your child first do each of the following?

$\begin{array}{lllllll} & \begin{array}{c}\text { less than } \\ \mathbf{1} \text { year }\end{array} & \mathbf{1 - 2} \text { years } & \mathbf{3 - 4} \text { years } & \mathbf{5 - 6} \text { years } & \begin{array}{c}\text { don't } \\ \text { know }\end{array} & \begin{array}{c}\text { child } \\ \text { doesn't } \\ \text { do this }\end{array} \\ \text { watched TV } & 1 & 2 & 3 & 4 & 5 & 6 \\ \text { watched videos / DVDs } & 1 & 2 & 3 & 4 & 5 & 6 \\ \text { listened to the radio } & 1 & 2 & 3 & 4 & 5 & 6 \\ \text { listened to the stereo } & 1 & 2 & 3 & 4 & 5 & 6 \\ \text { used the computer } & 1 & 2 & 3 & 4 & 5 & 6 \\ \text { played with a game console } & 1 & 2 & 3 & 4 & 5 & 6 \\ \text { used a telephone / cell phone } & 1 & 2 & 3 & 4 & 5 & 6\end{array}$

In the last section, the questions are related to your child's attitudes towards written language.

33. How many letters of the alphabet does your child know?
1. none
2. few
3. about a half
4. almost all
5. all

34. Can your child read?
1. yes
2. no
3. don't know

35. If your child can already read, at what age was he/she when he/she learned to read?
1. 2 years or less
2. 3 years
3. 4 years
4. 5 years
5. 6 years

36. Is your child interested in finding out what is written, for example, in the texts on television, in the ads coming home or in shop windows or signs? Choose one option that describes your child the best.

1. doesn't ask

2. asks what it says in them

3. tries to recognize or read letters from them by him/herself

37. How interested is the child to find out about the printed text in the following situations?

text on television

texts of different magazines

ads coming at home

shop signs, road signs, etc.

other texts at home (e.g., on a milk carton)

when reading a book, comic book or a magazine

$\begin{array}{cccc}\text { very } & \text { quite } & \text { a bit } & \text { not } \\ \text { interested } & \text { interested } & \text { interested } & \text { interested }\end{array}$ don't know

$\begin{array}{ccccc}1 & 2 & 3 & 4 & 5 \\ 1 & 2 & 3 & 4 & 5 \\ 1 & 2 & 3 & 4 & 5 \\ 1 & 2 & 3 & 4 & 5 \\ 1 & 2 & 3 & 4 & 5 \\ 1 & 2 & 3 & 4 & 5\end{array}$


38. How often does your child write or pretend to write text?
1. every day
2. 2-6 times a week
3. about once a week
4. rarely
5. never

39. Is your child interested in writing?
1. very interested
2. quite interested
3. a bit interested
4. not interested
5. don't know

40. Your child recognizes words ... (Choose all that apply.)
1. based on familiar letters
2. based on color or shape
3. child can already read
4. don't know

Thank you very much for your answers! 